\title{
Economic performance of production of Croatian cheese ripened in a lamb skin sack (Sir iz mišine)
}

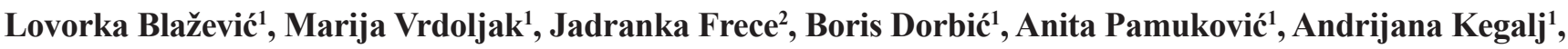 \\ Sandra Mandinićc
}

${ }^{1}$ University of Applied Scienses ,,Marko Marulić“ in Knin, Krešimirova 30, 22300 Knin, Croatia.

${ }^{2}$ University of Zagreb, Faculty of Food Technology in Zagreb, Department of Biochemical Engineering, Pierottijeva 6, 10000 Zagreb.

${ }^{3}$ University of Zagreb, Faculty of Agriculture, Department of Management and Rural Entrepreneurship, Svetošimunska 25, 10000 Zagreb, Croatia

*Corresponding author: mvrdoljak@veleknin.hr

\begin{abstract}
Cheeses matured in skin sack is traditionally produced in several Mediterranean countries, which in Croatia has been retained in the territory of Dalmatian hinterland. The characteristic of this cheese is its piquant flavour and aroma, as a consequence of ripening in anaerobic conditions in lamb skin. This type of cheese has been recognised and has its customers in the wider area of the Croatia, and it is an interesting touristic product. The major constraint is that the production of this type of cheese in Croatia has been reduced to sporadic production in several families that preserve the tradition of their ancestors and the produced quantities are insufficient to meet custemers needs. In 2009, Dalmatian hinterland had 11 registered producers of this type of cheese, while there are currently only 2. A production and economic analysis was performed of the remaining producers in order to determine the production performance. Both family farms produce cheese from sheep milk, while the first farm owns 300 sheep and the second 500. The selling price of cheese reaches HRK 150 per kilo, which ensures the achievement of cost-effectiveness of production. The producers point out that all the produced quantity is sold to known customers through on-farm sales and the demand exceeds the supply. Such a product would arise extreme interest among tourists, while the basic prerequisite for that is increase of the anuual production of cheese by increase of the number of producers, as well as their clustering and protection of the product by one of the quality marks at the EU level.
\end{abstract}

Key words: cheese in lamb skin sack, economic performance, Dalmatian hinterland

\section{Introduction}

The technology of cheeses ripened in animal skin sacks is the closest to the original one depicted by ancient cultures and that traditional technology has been retained in some areas of Mediterranean countries to this day. Nomadic tribes stored milk in lamb skin sacks in which milk coagulated under the influence of warm climate through fermentation, while long journeys and shaking resulted in production of whey and curd cheese. According to references, these cheese types are produced in Croatia (Sir iz mišine), Bosnia and Herzegovina (Sir iz mijeha), Montenegro (Sir iz mijeha), Turkey (Tulum, Kulek), Greece (Touloumi), Algeria (Bouhezza) and Lebanon (Darfiyeh) (Grbavac, 2002; Bijeljac, 2004; Yilmaz et al., 2005; Hayaloglu et al., 2007; Dervisoglu and Aydemir, 2007; Cakmakci et al., 2008; Serhan et al., 2009; Aissaoui Zitoun et al., 2012. Hayaloglu and Karabulut, 2013). A common feature of this type of cheeses is ripening process that occurs during the period of 2 to 3 months in lamb or goat skin. Animal skin (locally referred to as mijeh, mišina, tulum, chekoua) is the media ensuring anaerobic conditions and reducing the moisture from cheese during ripening, which enables more intensive biochemical processes such as proteolysis and lipolysis which result with the piquant cheese flavour and aroma (Tudor Kalit et al., 2012). According to the water content in fat-free dry matter, such cheese types can be classified as hard or semi-hard cheese, while according to the fat content in the total dry matter, they can be classified as full fat or semi-fat cheese (Vrdoljak, 2016; Tudor Kalit et al., 2010).

Autochthonous cheeses ripened in animal skin sacks are specific products with a local character, which are produced in limited series on family farms (Tudor Kalit et al., 2010). Products deriving from a limited geographical area and whose production contributes to the preservation of local knowledge and local specific resources undoubtedly contribute to increasing the quality of life of both producers and consumers, and

in the broader sense of entire communities (Bramley, 2011). Traditional and typical products are the result of complex production systems strictly interrelated with many dimensions of territorial development going beyond economic issues to involve social and environmental dimensions, as well (Samardzic et al., 2013). There is a large number of authentic products in Croatia, while just some of them are protected with quality marks. Autochthonous ecological products (primarily produced at organic farms and agricultural households in Croatia) are very important, but they still do not have an adequate market position (Popović and Dragićević, 2019). The uniqueness of cheese ripened in animal skin sack makes this product very appealing not only as foodstuff, but as also as cultural heritage admired by all visitors of Herzegovina. The potential that this cheese bears should be utilised as a driver for fostering rural development in Herzegovina region (Samardzic et al., 2014). In Croatia this type of cheese is produced at family farms of Dalmatian hinterland (primarily in Šibenik - Knin region), Velebit and a part of Lika, where it is extremely valued as a product among the local population. It is primarily produced at family farms whose annual production reaches from $5,000 \mathrm{~kg}$ to $10,000 \mathrm{~kg}$ (Vrdoljak, 2016). Research aim is to determine the production performance on two different types of farms, (conventional and organic).

\section{Materials and methods}

The research includes an in-depth interview with owners of two family farms in the region of Dalmatian hinterland. The interview was conducted in February 2020. Aim of interview was to collect all data necessary to calculate economic performances for two different type of the production (conventional and organic) of the cheese in the sack. 
The producers were asked 30 open-ended questions to which they responded freely. The questions were divided into several sets. The first set of questions referred to basic information about the family farm (e.g. members of the family farm, average age of the members of the family farm and geographical location of the family farm). The second set of questions referred to collection of information about registration and launching production, investment into the farm and investment structure. The third set of questions referred to collection of financial data -revenue and its structure, expenditure and its structure and specific features of individual items in revenue and expenditure. The fourth set of questions referred to collection of information about cheese production technology, types of cheese produced, specific features of traditional production, the future, benefits and drawbacks of cheese production in lamb skin sack and constraints of cheese production in lamb skin sack. The fifth set of questions was concerning demographic issues, the depopulation problem and the way in which it affects the operations of the observed farms, possibilities of forming co-operatives and clusters of the observed farms, possibilities to protect cheese ripened in lamb skin sack with a quality mark and questions on specific features of individual farms. The sixth set of questionsreferred to possibilities of diversification of supply. All these questions enabled to provide a broader picture of the issues concerning the production of Sir iz mišine. The results were processed using standard Microsoft excel.

\section{Results and discussion}

\section{Family farm 1 (organic producer)}

The first family farm (Table 1) started with agricultural activity 1995. Over the last several years this farm has been striving to decrease the size of its basic flock and it currently owns 300 sheep. It is a family whose members are elderly, without heirs who would be interested in continuing of cheese production and therefore cheese production could cease upon their retirement. Due to the previously mentioned reason, they are not considering the future of their production, since they are aware upon their own example that young people do not want to become involved in family business and hence they do not even have a wish to form clusters or to protect cheese with a quality mark.

Table 1. The basic indicators of cost-effectiveness of organically raised livestock and cheese production with 300 sheep in accordance with organic principles

\begin{tabular}{|c|c|c|c|c|}
\hline REVENUE & Quantity & $\begin{array}{c}\text { unit of } \\
\text { measurement }\end{array}$ & $\begin{array}{l}\text { price per unit } \\
\text { (HRK) }\end{array}$ & total amount (HRK) \\
\hline Lambs & 280 & head & 750.00 & $210,000.00$ \\
\hline Sir iz mišine & 1710 & $\mathrm{Kg}$ & 150.00 & $256,500.00$ \\
\hline breeding rams & 0 & & & - \\
\hline breeding young sheep & 0 & & & - \\
\hline culled ewes & 90 & head & 200.00 & $18,000.00$ \\
\hline wool & 0 & & & - \\
\hline farmyard manure & 0 & & & - \\
\hline incentives per head of sheep & 285 & head & 125.00 & $37,500.00$ \\
\hline incentives for grazing land (40ha) & 40 & $\mathrm{Ha}$ & $1,300.00$ & $52,000.00$ \\
\hline A. TOTAL REVENUE & & & & $574,000.00$ \\
\hline EXPENDITURE & Quantity & $\begin{array}{c}\text { unit of } \\
\text { measurement }\end{array}$ & $\begin{array}{l}\text { price per unit } \\
\text { (HRK) }\end{array}$ & total amount(HRK) \\
\hline Fodder & & & & $220,000.00$ \\
\hline mineral salt $(2080 \mathrm{~kg})$ & 2080 & $\mathrm{~kg}$ & 2.50 & $5,200.00$ \\
\hline mineral salt blocks for lambs & 16 & weeks & 30.00 & 480.00 \\
\hline flock renewal rate - young rams & 5 & $\begin{array}{l}\text { young rams } \\
\text { from organically } \\
\text { raised flock }\end{array}$ & $1,500.00$ & $7,500.00$ \\
\hline veterinary costs & & & & $20,000.00$ \\
\hline Rennet & & & & $2,000.00$ \\
\hline $\begin{array}{c}\text { lamb skin sack foraround } 20 \mathrm{~kg} \text { of } \\
\text { cheese }\end{array}$ & 90 & piece & 100.00 & $9,000.00$ \\
\hline slaughtering lambs & 280 & piece & 70.00 & $19,600.00$ \\
\hline sheep shearing & 300 & piece & 15.00 & $4,500.00$ \\
\hline shepherd salary & 2 & shepherds & $7,500.00$ & $15,000.00$ \\
\hline wool management & & & & 0 \\
\hline
\end{tabular}




\begin{tabular}{|c|c|c|c|c|}
\hline electricity (1500/month) & & & & $18,000.00$ \\
\hline water charges & & & 400.00 & $39,000.00$ \\
\hline grazing tax (50ha Croatian forests) & 50 & Ha & 25.00 & 300.00 \\
\hline $\begin{array}{c}\text { costs of analysis of physical and } \\
\text { chemical properties of milk }\end{array}$ & 12 & piece & $2,000.00$ & $2,000.00$ \\
\hline swabs for cheese dairy - laboratory & 1 & piece & 150.00 & 300.00 \\
\hline costs of microbiological analyses & 2 & piece & & $35,000.00$ \\
\hline control of organic production & & & & $176,120.00$ \\
\hline B. TOTAL EXPENDITURE & & & & 1.44 \\
\hline INCOME (A-B) & & & & \\
\hline COST EFFECTIVENESS (A/B) & & & & \\
\hline
\end{tabular}

In addition to investment of own funds in the purchase of the basic flock, $2 / 3$ of the resources for the construction of the dairy were provided through a loan programme, while $1 / 3$ was financed through a programme provided by the Ministry of Agriculture. The family farm is regularly financed through programmes that it applies for, primarily for resources provided by Šibenik - Knin County. Several years ago, it received resources for the construction of cheese tasting room, as well as for tourist accommodation in order to expand their products and services. In addition to the dairy, they own a sheep barn, milking equipment, hay harvesting equipment and other agricultural machinery required for the performance of their activity.

The owners explained why there is no revenue from breeding rams and young sheep. The reason that has been provided is that in Croatia there is no demand for these types of products and there is no sale at all, not withstanding the fact that they are registered as organic farmers. Culled ewes are sold at the price of HRK 200.00 per head for curing and production of the so-called "kaštradina" -a traditional autochthonous product typical of the region of Dalmatian hinterland (dry-cured mutton). Producers pointed out wool management as a major problem, since there is no organised purchase and wool is actually a by-product. All the raised lambs are sold exclusively on their farm and hence they do not incur additional transport costs, in addition to the transport to the slaughterhouse. The revenue from the Sir iz mišine is also generated on their farm, and also several years ago they used to go to trade fairs. A significant proportion of their cheese is sold to organised tours for tourist groups who visit the family farm, taste the cheese, make a tour of the farm and purchase some cheese.

The owners pointed out water charges as a significant expenditure item. The family farm is located in a village where there is no water supply and hence every two days the owner of the family farm pays for transport of water for the sheep and the dairy plant. Every year the owner of the farm purchases young rams for flock renewal on the island of Brač (organic farming). He stated that the price of HRK 1,500.00 per head is high. He pointed out that he pays higher prices for everything compared with conventional producers because he is a certified organic farmer. As a significant expenditure, he pointed out the costs of control of organic farming that reach HRK 15,000.00 annually.

Table 1 shows that the farm operates successfully and, irrespective of high expenditures, it achieves a satisfying cost effectiveness. The family farm pointed out that there are no problems with cheese sales and that they manage to sell all the produced quantities at satisfying prices. The story of this family farm is typical and it shows problems faced by this type of farms in Croatia - the farm has no heir and it is hence not interested in increasing its production or in creation of a cheese trademark. A conclusion can be reached that in this case there are no problems with economic indicators of production, which could be improved without significant investment, but the major problem is the depopulation of the village and negative perception of agriculture among young people who are supposed to continue and promote production.

\section{Family farm 2 (conventional producer)}

The second family farm (Table 2) comprises of four members and they all participate in production assisted by three shepherds. Farm owners are middle-aged spouses and they are assisted by two adult children. The basic flock of sheep comprises of 500 head. The farm started operating in 1998 with 50 sheep. In 2009, they registered their farm business and constructed a dairy on the ground floor of their family house using their own capital, as well as sheep barns, grazing barns and they purchased a truck. The dairy equipment worth HRK 160,000.00 was financed from EU funds through SAPARD programme. They initially sold cheese in Drniš, yet during the last several years they have been selling cheese exclusively on their farm. The owners pointed out that they are not very interested in clustering, since in the entire area of Dalmatian hinterland there are only 2 or 3 registered dairies and that is an insufficient number for clustering.

Table 2. Basic indicators of cost-effectiveness of livestock production and cheese production with 500 sheep in accordance with the principles of conventional production

\begin{tabular}{|c|c|c|c|c|}
\hline \multicolumn{2}{|c|}{ quantity } & \multicolumn{1}{c}{$\begin{array}{c}\text { unit of } \\
\text { measurement }\end{array}$} & $\begin{array}{c}\text { price per unit } \\
\text { (HRK) }\end{array}$ & total amount (HRK) \\
\hline Lambs & 468 & piece & 750.00 & $351,000.00$ \\
\hline Sir iz mišine & 2880 & $\mathrm{~kg}$ & 150.00 & $432,000.00$ \\
\hline breeding rams & & & & - \\
\hline breeding young sheep & & & & - \\
\hline culled ewes & 156 & piece & 200.00 & $31,200.00$ \\
\hline
\end{tabular}




\begin{tabular}{|c|c|c|c|c|}
\hline wool & 0 & & & - \\
\hline farmyard manure & 0 & & & - \\
\hline incentives per head of sheep & 480 & piece & 90.00 & $43,200.00$ \\
\hline incentives for grazing land (40ha) & 50 & $\mathrm{Ha}$ & $1,300.00$ & $65,000.00$ \\
\hline A. TOTAL REVENUE & & & & $922,400.00$ \\
\hline EXPENDITURE & quantity & $\begin{array}{c}\text { unit of } \\
\text { measurement }\end{array}$ & $\begin{array}{l}\text { price per unit } \\
\text { (HRK) }\end{array}$ & total amount (HRK) \\
\hline fodder & & & & $290,000.00$ \\
\hline mineral salt $(2080 \mathrm{~kg})$ & 3500 & $\mathrm{~kg}$ & 2.50 & $8,750.00$ \\
\hline mineral salt blocks for lambs & 16 & weeks & 51.00 & 816.00 \\
\hline flock renewal rate - young rams & 7 & young rams & 750.00 & $5,250.00$ \\
\hline veterinary costs & & & & $34,000.00$ \\
\hline rennet & & & & $3,400.00$ \\
\hline lamb skin sack for around $20 \mathrm{~kg}$ of cheese & 144 & piece & 100.00 & $14,400.00$ \\
\hline slaughtering lambs & 468 & piece & 70.00 & $32,760.00$ \\
\hline sheep shearing & 500 & piece & 15.00 & $7,500.00$ \\
\hline shepherd salary & 3 & shepherds & $7,500.00$ & $22,500.00$ \\
\hline wool management & & & & - \\
\hline electricity (1500/month) & & & & $25,000.00$ \\
\hline water charges & & & & $10,000.00$ \\
\hline grazing tax (50 ha Croatian forests) & 50 & $\mathrm{Ha}$ & 400.00 & $20,000.00$ \\
\hline $\begin{array}{l}\text { costs of analysis of physical and chemical } \\
\text { properties of milk }\end{array}$ & 12 & month & 25.00 & 300.00 \\
\hline swabs for cheese dairy - laboratory & 1 & piece & $2,000.00$ & $2,000.00$ \\
\hline costs of microbiological analyses & 2 & piece & 150.00 & 300.00 \\
\hline control of organic production & & & & - \\
\hline B. TOTAL EXPENDITURE & & & & $476,976.00$ \\
\hline INCOME (A-B) & & & & $445,424.00$ \\
\hline COST EFFECTIVENESS (A/B) & & & & 1.93 \\
\hline
\end{tabular}

The revenue generated by the farm is the revenue from lambs and the revenue from cheese matured in lamb skin sack. Both lambs and cheese are sold exclusively on the farm. Like the previously described farm, they do not sell rams and young sheep for breeding because there is no demand for them. Table 2 shows that the farm operates successfully and generates a satisfactory income, as well as that it achieves cost-effectiveness. Since the farm is not a certified organic farm, some expenses are lower compared with the previously analysed family farm (e.g. expenditure for young rams for flock renewal, there are no expenditures for control of organic production). Irrespective of that, selling prices of cheese, lambs and culled ewes achieved by the farm are identical to the previously analysed organic farm producer, which provides additional evidence that our market still insufficiently values organic farming. The same conclusion was reached by Očić et al., (2019) who have shown that farms do not succeed in achieving adequate prices for their organic products, as opposed to "conventional products". Therefore, an additional effort needs to be invested in marketing activities and development of market infrastructure that would help such farms to operate more successfully. Furthermore, this farm uses puddle water for its flock of sheep while grazing and hence its water charges are significantly lower. As opposed to the previously analysed farm, this farm has heirs who will continue production. They are consequently increasing cheese production and they make up a vital segment of the Croatian family farms that can be seriously counted on.

\section{Conclusions}

Cheeses ripened in lamb skin sack are traditionally produced in Mediterranean countries, which in our country has been retained in the territory of Dalmatian hinterland (primarily Šibenik - Knin region), Velebit and a part of Lika. Irrespective of high demand for this type of cheese, as well as the sales potential in tourism regions, a large decrease in the number of producers is a problem. It has been caused by the depopulation of rural areas and unattractiveness of rural life as perceived by young people who are supposed to continue and promote this type of production. This paper analyses production and economic data provided by two family farms from Dalmatian hinterland, one of which is involved in organic livestock farming of 300 sheep in a flock, while the other farm does not hold an organic production certificate and owns 500 sheep in a flock. The analysis has shown that both family farms operate successfully (cost effectiveness of the first family farm is 1.44 and of the second 1.93) and they have no problems with cheese sales, as they could even sell more cheese compared with what is currently the case. They are involved in on-farm sales and one of the problems is also the fact 
that customers do not recognise or pay attention to the organic farming label of the product, due to which such producers do not manage to achieve higher selling prices in relation to other producers, while their production costs are higher. Irrespective of the fact that the two family farms have no problems with economic performance of production, the first family farm has no heir. There is hence no interest in improvement of production and it will probably wind up in several years. Therefore, agricultural policy measures are required with the aim to encourage young people to remain in rural areas. In addition to currently existing financial incentives and subsidies, raising awareness of young people is imperative by showing them that agriculture is a desirable way of life that provides sufficient income for a reasonable standard of living. Moreover, developing rural infrastructure is vital, as well as enabling rural population to achieve the standard similar to that achieved by urban population (e.g. Internet infrastructure, road infrastructure, schools and kindergartens and cultural opportunities), since that is the fundamental prerequisite for young people to return and remain in rural areas.

\section{References}

Aissaoui Zitoun O., Pediliggieri C., Benatallah L., Lortal S., Licitra G., Zidoune N.M., Carpino S. (2012) Bouhezza, a traditional Algerian raw milk cheese, made and ripened in goatskin bags. Journal of Food, Agriculture and Environment, 10 (2) 289-295.

Bijeljac S. (2004) Sir iz mijeha. Udruga „Pramenka“. Mostar.

Bramley C. (2011) A review of the socio-economic impact of geographical indications: considerations for the developing world. Paper prepared for presentation at the WIPO Worldwide Symposium on GeographicalIndications, 22-24, Lima.

Cakmakci S., Dagdemir E., Hayaloglu A.A., Gurses M., Gundogdu E. (2008) Influence of ripening container on the lactic acid bacteria population in Tulum cheese. World Journal of Microbiology and Biotechnology, 24 293-299.

Dervisoglu M., Aydemir O. (2007) Physicochemical and microbiological characteristics of Kulek cheese made from raw and Heat-treated milk. Word Journal Microbiology Biotechnology, 23 451-460.

Grbavac J. (2002) Istraživanje proizvodnje i kakvoće sira iz mješine pod nazivom Ovčji planinski sir iz Zapadne Hercegovine. Magistarski rad, Veterinarski fakultet Sveučilišta u Zagrebu.

Hayaloglu A.A., Fox P.F., Guven M., Cakmakci S. (2007) Cheeses of Turkey: 1. Varieties ripened in goat-skin bags. Lait, 87 79-95.

Hayaloglu A.A., Karabulut I. (2013) Primary and secondary proteolysis in eleven Turkish cheese varieties. International Journal of Food Properties, 16 1663-1675.

Očić V., Rukavina M., Batelja L. K., Šakić Bobić B. (2019) Ekonomska uspješnost ekološke proizvodnje oraha i lješnjaka-poslovna praksa. Agroeconomia Croatica, 9 (1) 124-131.

Popovic I., Dragicevic M. (2019) Tourists Attitudes Toward Autochthonous Product Quality and Placement—The Case of Dubrovnik, Croatia. In: Vasile V. (eds) Caring and Sharing: The Cultural Heritage Environment as an Agent for Change. Springer Proceedings in Business and Economics. Springer, Cham.

Samardzic S., Berjan S., El Bilali H., Bajramović S., Ostojić A. (2013) Quantitative and qualitative effects of protecting traditional agro-food products by geographical indications 4th International Symposium “Agrosym 2013” At: Jahorina (East Sarajevo), Bosnia and HerzegovinaVolume: Proceedings, 1117-1123.

Samardzic S., El Bilali H., Bajramović S., Kanlic V., Ostojic A., Berjan S., Savkovic A. (2014) Cheese in a Suck: Exploring History, Production Area and Production Process of a Typical Herzegovinian Product. International Journal of Environment and Rural Development, 5 (2) 74-79.

Serhan M., Cailliez-Grimal C., Borges F., Revol-Junelles A., Hosri C., Fanni J. (2009) Bacterial diversity of Darfyeh, a Labanese artisinal raw goat`s milk cheese. Food Microbiology, 26 645-652.

Tudor Kalit M., Kalit S., Havranek J. (2010) An overview of researches on cheeses ripening in animal skin. Mljekarstvo, 60 (3) $149-155$.

Tudor Kalit M., Kalit S., Kelava N., Havranek J. (2012) Physicochemical differences between Croatian cheese matured in a lamb skin sack (Sir iz misine) and cheese matured in a rind throughout ripening. International Journal of Dairy Technology, 65 (4) 555-560.

Vrdoljak M. (2016) Probiotičke kulture Lactobacillus plantarum B i Lactococcus lactis subsp. lactis S1 u poboljšanju funkcionalnih svojstava sira iz mišine. Disertacija. Sveučilište u Zagrebu, Agronomski fakultet. Zagreb.

Yilmaz G., Ahmet A., Akin N. (2005) The effect of microbial lipase on the lipolysis during the ripening of Tulum cheese. Journal of Food Engineering, $69269-274$. 